\title{
SPATIOTEMPORAL VARIATION IN THE PRECIPITATION OF THE AMAZON COASTAL ZONE: USE OF REMOTE SENSING AND MULTIVARIATE ANALYSIS
}

\author{
SANTOS, Marcos Ronielly Silva - mronielly@yahoo.com.br \\ Universidade Federal do Pará / UFPA \\ VITORINO, Maria Isabel - vitorino@ufpa.br \\ Universidade Federal do Pará / UFPA \\ PEREIRA, Luci Cajueiro Carneiro - luci.cajueiro@gmail.com \\ Universidade Federal do Pará / UFPA
}

\begin{abstract}
Reliable data on the spatiotemporal variability in precipitation patterns are vital to the development of effective public policies for environmental management. The analysis of the variation in rainfall rates is currently limited severely by the dependence on data from rain gauges, in particular in regions with a relatively sparsely-distributed network of meteorological stations, as in the Amazon region. The present study investigated the variability in the precipitation and the principal rainfall patterns at different time scales in the coastal zone of the Amazon region, and associated these patterns with the precipitant meteorological systems present in the region. The study was based on the application of remote sensing (Climate Prediction Center morphing method - CMORPH) data taken at half-hourly intervals on a 0.07 degrees latitude/longitude scale. The spatiotemporal variability in the region's precipitation was analyzed at different time scales (monthly, seasonal, and annual), with distribution patterns being assessed using a Principal Components Analysis (PCA). The estimates obtained from the CMORPH data provided a satisfactory overview of the precipitation climatology of the study region at the distinct time scales, compared to surface data. The PCA identified a precipitation gradient in the two principal pluviometric modes, which together explained $88 \%$ of the total variance in the data. The first mode explained $83 \%$ of the variance, with two distinct periods, a rainy season and a dry (or less rainy) period, which are influenced by large-scale precipitant systems, the Intertropical Convergence Zone (ITCZ) and High Level Cyclonic Vortices (HLCVs). The second mode, which explains $5 \%$ of the variance in the rainfall data, is associated with mesoscale systems that affect primarily the transition periods between the seasons, and depend on the southern extreme of the annual shift in the ITCZ. The understanding of the variation of precipitation patterns using highresolution CMORPH data, with a comprehensive coverage in both time and space, provides an effective tool for the establishment of public policies at a municipal level, in particular the development of models, and the mediation of the vulnerability of local populations to climatic extremes.
\end{abstract}

KEYWORDS: Precipitation, Coastal, Amazonia, Remote Sensing.

VARIAÇÃO ESPAÇO-TEMPORAL NA PRECIPITAÇÃO DA ZONA COSTEIRA AMAZÔNICA: USO DO SENSORIAMENTO REMOTO E ANÁLISE MULTIVARIADA

RESUMO: Representações confiáveis sobre a variabilidade espaço temporal da precipitação é um dos principais fatores para alcançar o planejamento eficiente de políticas públicas. Atualmente, as representações exatas da variabilidade das chuvas está severamente limitada a dados coletados por meio de pluviômetros, particularmente em grandes regiões e com escassez de dados - caso típico da região Amazônica. Neste cenário, esta pesquisa propõe analisar a variabilidade da precipitação e dos principais padrões da chuva em diferentes escalas de tempo, para uma região costeira da Amazônia, associando-os aos sistemas meteorológicos precipitantes que atuam na região. O estudo apresenta a aplicação do produto de sensoriamento remoto (Climate Prediction Center morphing method - $\mathrm{CMORPH}$ ) com dados de meia em meia hora e com 
$0,088^{\circ}$ de latitude e longitude. A variabilidade espaço-temporal da precipitação foi representada pela climatologia dos tempos (mensais, sazonais e anuais) e para obtenção dos padrões de chuva utilizou-se a técnica de Análise de Componentes Principais (ACP). As estimativas obtidas pelo CMORPH evidenciaram de forma satisfatória a climatologia da precipitação para as distintas escalas de tempo, em comparação aos dados de superfície. A ACP determinou a existência de um gradiente de precipitação nos dois principais modos pluviométricos, que explicam $88 \%$ da variância total dos dados. O primeiro modo, explica $83 \%$ dos dados, evidenciando o período chuvoso e menos chuvoso da região, com a atuação dos sistemas precipitantes de grande escala: Zona de Convergência Intertropical (ZCIT) e Vórtices Ciclones de Altos Níveis (VCANs). O segundo modo explica $5 \%$ dos dados de chuva e está associado a ocorrência de sistemas de mesoescala, que ocorrem nos inícios das estações, e ao posicionamento da ZCIT mais ao sul da região. $O$ conhecimento da variabilidade da precipitação em alta resolução de forma contínua no tempo e no espaço torna-se uma ferramenta eficaz para a tomada de políticas públicas a nível municipal, corroborando para estudos de modelagem e auxiliando na prevenção da vulnerabilidade climática.

PALAVRAS-CHAVE: Precipitação, Costa, Amazônia, Sensoriamento Remoto VARIACIÓN ESPACIAL Y TEMPORAL DE LA PRECIPITACIÓN EN LA ZONA COSTERA
AMAZONICA: USO DEL SENSORIAMIENTO REMOTO Y ANÁLISIS MULTIVARIADA

RESUMEN: Las representaciones confiables sobre la variabilidad espacial y temporal de la precipitación, es uno de los principales factores para alcanzar una planificación eficiente de las políticas públicas. En la actualidad, la variabilidad de las lluvias está fuertemente limitada a los datos colectados a través de los pluviómetros, particularmente en grandes regiones y con escasez de datos, caso típico de la región amazónica. En este escenario, esta investigación propone analizar la variabilidad de la región costera amazonica, asociado a los sistemas meteorológicos relacionados con la precipitación que acontecen en la región. El estudio presenta una aplicación producto del sensoramiento remoto (Climate Prediction Center morphing method - $\mathrm{CMORPH}$ ) con datos de media hora y 0.088 de latitud y longitud. La variabilidad espacial y temporal de la precipitación fue representada por la climatología en diferentes tiempos (mensuales, estacionales y anuales) y para la obtención de los patrones de lluvias se utilizó la técnica Análisis de Componentes Principales (ACP). Las estimativas obtenidas por la técnica CMORPH evidenciaron de forma satisfactoria la climatología de la precipitación para las distintas escalas de tempo, en comparación con los datos de superficie. La ACP determinó la existencia de un gradiente de precipitación en dos principales modos pluviométricos que explican el $83 \%$ de los datos, evidenciando el periodo: lluvioso y menos lluvioso de la región, con la actuación de los sistemas precipitantes de gran escala: Zona de Convergência Intertropical (ZCIT) y Vórtices Ciclones de Altos Niveles (VCAN). EI segundo modo, explica el $5 \%$ de los datos de lluvia y está asociado a la ocurrencia de sistemas de mesoescala, que ocurren durante el inicio de las estaciones y al posicionamiento de la ZCIT más al sur de la región. El conocimiento de la variabilidad de la precipitación en altas resolución de forma continua en el tiempo y en el espacio, tórnase una herramienta eficiente para la toma de decisiones en políticas públicas a nivel mundial, corroborando para estudios de modelaje y auxiliando en la prevención de la vulnerabilidad climática.

PALABRAS-CLAVE: Precipitación, Costa, Amazonía, Sensoramiento Remoto

\section{INTRODUCTION}

Studies of the spatial and temporal variation in the rainfall patterns of coastal regions are still incipient (ZAMBRANO-BIGIARINI et al., 2017), especially considering the dynamic interactions between continental and oceanic systems that are typical of these regions (RODRIGUEZ, WINDEVOXHEL, 1998). Kousky (1980) found that the diurnal cycle in the precipitation of the coastal region of northeastern Brazil peaks during the nocturnal period, probably are the result of 
the convergence between onshore winds and offshore land breezes. Many precipitation studies are based on terrestrial data. However it may limit considerably the sampling of spatiotemporal variability, by being restricted to specific points that provide the database for the development of climatic and hydrological models derived from the interpolation of the precipitation data points (VERWORN, HABERLANDT, 2011; ROGELIS, WERNER, 2013).

Brazil has the longest coastline of any South American country, with a total extension of $8500 \mathrm{~km}$, including all its indentations, bays, and gulfs (PEREIRA, 2009). This country is located within the Neotropical biogeographic realm, which has a high diversity of local ecosystems, and integrates both natural and anthropogenic elements (SCHERER et al., 2010). The Amazon coast, which encompasses approximately $35 \%$ of the total Brazilian coastline, has a number of unique features, including both natural and anthropogenic phenomena. The natural elements include one of the world's largest continuous tracts of mangrove forest, the enormous input of sediments from the world's largest hydrographic basin, and extreme morphodynamic processes, resulting from high rainfall rates and the local macrotidal regime (KJERFVE, LACERDA, 1993; GEYER et al., 1996; AMANAJÀS, BRAGA, 2012; PEREIRA et al., 2014). The Amazon coast was also the first part of the region to be colonized by Europeans, and is now the most densely-populated sector, with the greatest concentration of urban centers in northern Brazil (BECKER, 2010; BRAZIL, 2018).

Rainfall is a key feature of coastal zones, given its influence on other climatological variables, such as temperature, relative humidity, and surface runoff (MORAES et al., 2005). In Amazonia, including the coastal sector, the rains occur predominantly during the austral summer and fall, which constitute the region's rainy season. This season is influenced by a number of meteorological systems functioning at different scales, including the Intertropical Convergence Zone (ITCZ) and Lines of Instability (LIs), which, combined with oceanic-atmospheric mechanisms, such as the Pacific Decadal Oscillation (PDO), North Atlantic Oscillation (NAO), and El Niño Southern Oscillation (ENSO), determine the intensification of the local rains (MOLION, 1987; COHEN et al., 1995).

Considering its high rainfall rates, the Amazon coastal zone has relatively few terrestrial meteorological stations (BRAZIL, 2018), which places considerable limitations on the potential for the development of detailed analyses of precipitation patterns. In general, the climatological series and precipitation data available for the Amazon region are based on readings from terrestrial stations, which tend to underestimate the influence of fluvial breezes and other phenomena functioning at regional and local scales (FITZJARRALD et al., 2008; COHEN et al., 2014). In developing countries and isolated regions such the the Amazon basin - meteorological stations tend to be sparsely distributed, leading to major uncertainties on the spatial distribution of precipitation patterns (WOLDEMESKEl et al., 2013).

Remote sensing techniques provide a promising alternative source of data that have been used increasingly to overcome many of the limitations of the precipitation data derived from terrestrial stations (ZAMBRANO-BIGIARINI et al., 2017). Remote sensing data have been widely used in research on coastal regions in a number of different parts of the world (CRACKNELL, 1999; 
MALTHUS, MUMBY, 2010), and these studies have shown that they can be an effective tool for the monitoring and analysis of oceanic, meteorological, and continental processes, in particular in areas that have a limited network of terrestrial meteorological stations (TRALLI et al., 2005; TOMLINSON et al., 2011). The CMORPH is a remote sensing procedure that provides precipitation estimates from passive microwaves, which are propagated in space by movement vectors, providing the best resolution for spatiotemporal data on precipitation patterns (JOYCE et al., 2004; ZEWELDI, GEBREMICHAEL, 2009).

The present study investigates the spatial and temporal variation in the precipitation of the Amazon coastal zone at different time scales, and analyzes the region's principal rainfall patterns in relation to its precipitant meteorological systems. This pioneering study was based on the CMORPH technique using data from the central sector of the Amazon coastal zone with a high spatial $(8 \mathrm{~km})$ and temporal (30 $\mathrm{min}$ ) resolution, covering the period between 1998 and 2016. This analysis provides important methodological insights that can be applied to other coastal regions, in both Brazil and other countries that have a reduced coverage of terrestrial meteorological stations or precipitation data of limited quality in terms of both time and space. It is hoped that these findings will contribute to the adoption of high resolution remote sensing data in future climatological research, providing a sound database for the development of effective public policies for the environmental management of coastal municipalities.

\section{MATERIAL AND METHODS}

\subsection{STUDY AREA}

The study area is the central portion of the Amazon coastal zone, which coincides with the northeastern extreme of the Brazilian state of Pará $\left(1^{\circ} 00^{\prime} 00^{\prime \prime}\right.$ $\mathrm{N}-2030^{\prime} 00^{\prime \prime} \mathrm{S}, 51^{\circ} 30^{\prime} 00^{\prime \prime}-46^{\circ} 00^{\prime} 00^{\prime \prime} \mathrm{W}$ ), covering an area of $69.000 \mathrm{~km} 2$. This area has a population of $3,664,593$ inhabitants, in 47 municipalities, representing almost half the population of the state, within only $6 \%$ of its land area (IBGE, 2018).

The study area was divided into three sectors for the purposes of the present study (Figure 1), representing different patterns of topography, vegetation cover, and land use. Land use is much more intense in sector 2 (mainland, estuary) in comparison with sector 1 (island), in particular in urban zones and more densely-populated areas. The ocean sector (3) was included to verify the potential influence of rainfall over the ocean on coastal processes. Most of sector 1 is low-lying, although the highest elevations in sector 2 are no more than $120 \mathrm{~m}$ above sea level (Figure 1). The low-lying areas are characterized by a considerable diversity of environments, such as beaches, estuaries, mangroves, swamps, and saltwater and freshwater marshes. The local climate is humid equatorial, with normal annual precipitation of 2000-3000 $\mathrm{mm}$, and mean annual temperatures of $26-28^{\circ} \mathrm{C}$ (BRAZIL, 2018). The seasonal fluctuations in the Intertropical Convergence Zone (ZITC) are the principal factor determining local precipitation levels, with the annual cycle being divided into two principal seasons, a rainy season, which normally lasts between December or January and May or June, and a dry (or less rainy) season during all other months. 


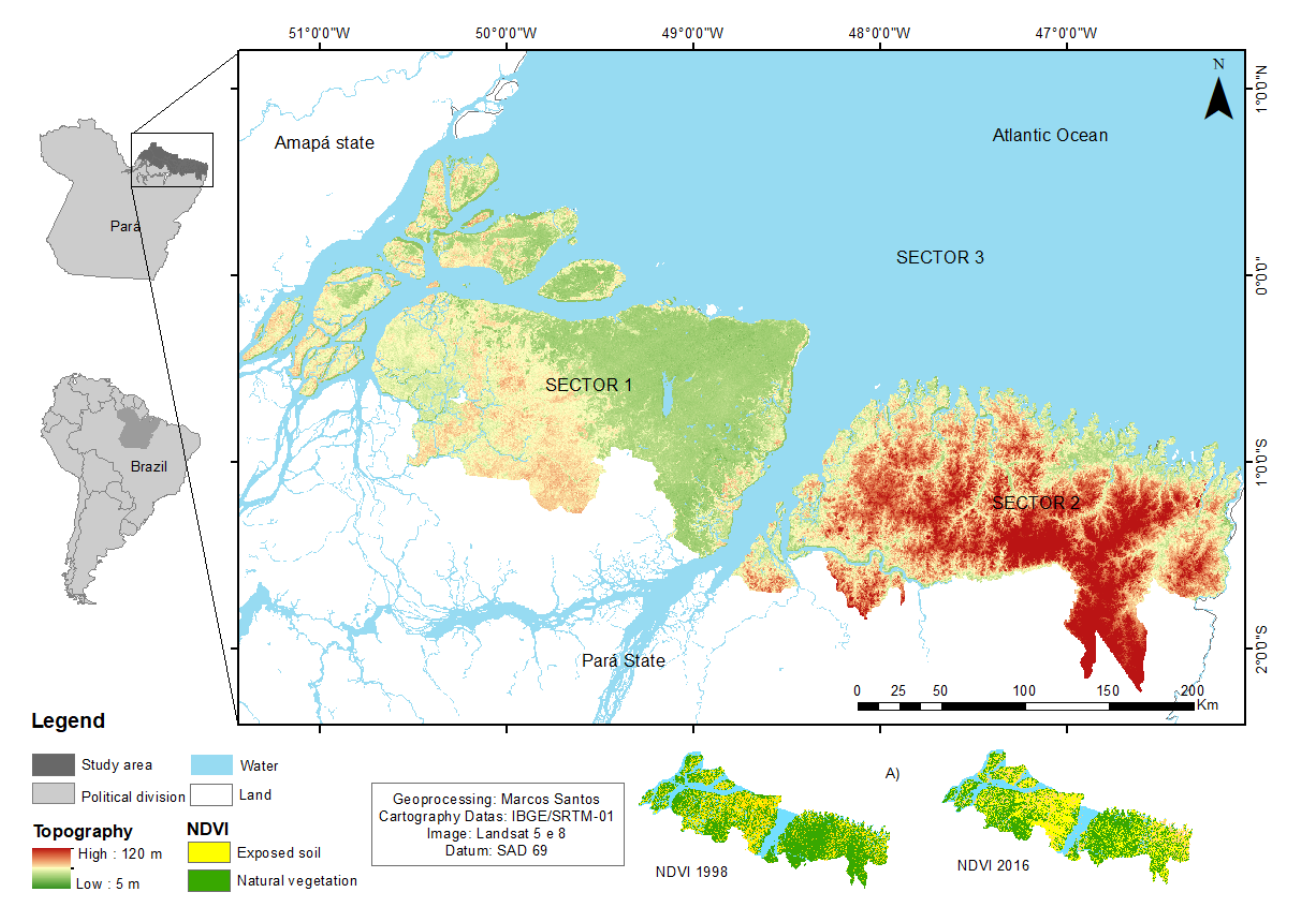

Figure 1 - Study area, showing the digital altitude, vegetation cover, and the three sectors analyzed in the present study ( $1=$ island sector; $2=$ mainland and estuarine sector; 3 = Atlantic Ocean sector).

\subsection{DATA}

The CMORPH, showed in Figure 2, was used to estimate precipitation data at a high spatial resolution $(8 \mathrm{~km} \times 8 \mathrm{~km})$ and short temporal resolution (30 $\mathrm{min}$ ). The time series of the precipitation data were analyzed by month, season, and year, between January, 1998, and December, 2016. The time series from the terrestrial stations located within the study area were also analyzed. These data were obtained from the Brazilian Meteorological Institute (INMET) for the period between January, 1998, and December, 2016. The level of correlation between the satellite and terrestrial data was determined to test the efficiency of the former for the interpolation of the latter data to areas with no terrestrial coverage. Data from the National Oceanic and Atmospheric Administration (NOAA) and scientific papers (ANDRADE et al., 2016; PEREIRA et al.; 2013, 2017) were used to evaluate the influence of extreme climatic events, such as El Niño, La Niña, and droughts. 


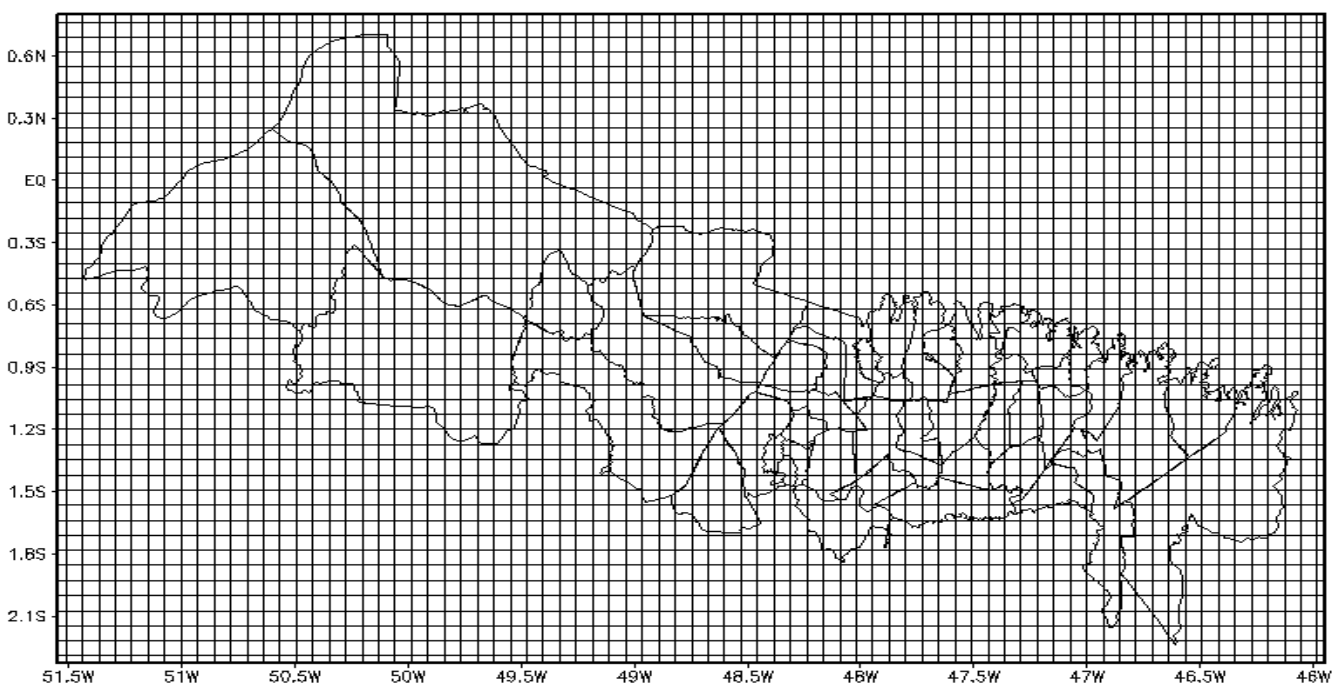

Figure 2 - Standard CMORPH grid.

\subsection{PROCEDURES}

The study area was divided into the three sectors for the analysis of the spatial distribution of the rainfall. The CMORPH data taken at 30-min intervals were used for the temporal analysis. The data were compiled by month, season, and year for the period between 1998 and 2016, and associated directly with the spatial grid. For the monthly analysis, the climatological data were compiled for each month of the study period. For the seasonal analyses, the year was divided into four quarters, the early rainy season (December, January, and February), the peak rainy season (March, April, and May), the rainy-dry transition months (June, July, and August), and the peak dry season (September, October, and November).

The annual analysis was based on the assessment of the variation between typical and atypical years. Typical years were considered to be the control for the comparative analysis of other years. Atypical years were characterized by the occurrence of extreme climatic conditions, i.e., El Niño and La Niña, based on comparisons with the climatic parameters of typical years (arithmetic means obtained from the pixels analyzed within the study area), ratified by the index of the Southern Oscillation and other published data (Figure 3).

The Southern Oscillation Index (SOI) was used to identify extreme climatic events. The SOI provides a quantitative measure of the development and intensity of the El Niño Southern Oscillation (ENSO), calculated from the difference in the mean atmospheric pressure between Tahiti and Darwin, Australia. This index reflects the cold (La Niña, SOI +) and warm (EI Niño, SOI ) phases of the ENSO phenomenon, as defined originally by Ropelewski and Jones (1987). Based on this, periods during which the SOI exceeded $-0.5^{\circ}$ for at least three months were defined as El Niño events, and the periods during which SOI values exceeded $+0.5^{\circ}$ for at least three months were classified as La Niña events (see NOAA, 2017). 


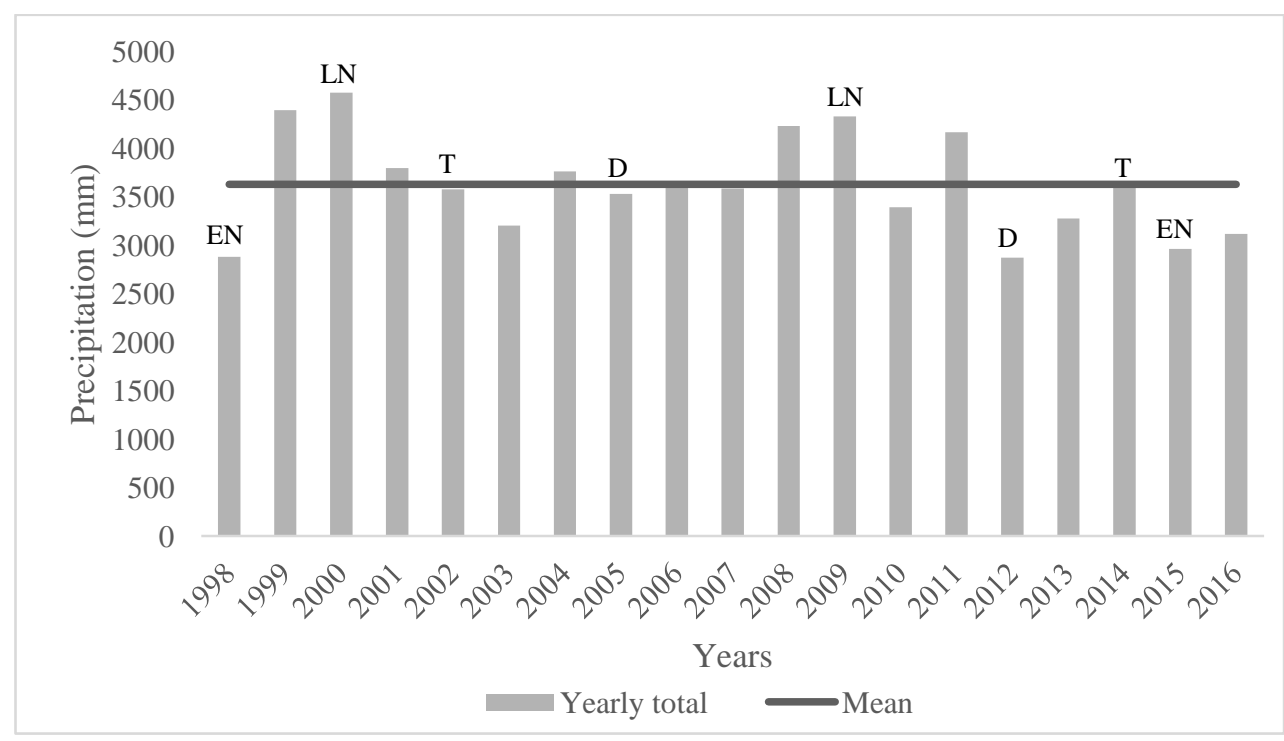

Figure 3 - Mean annual precipitation recorded in the study area between 1998 and 2016, showing the years selected as atypical for the purposes of the present study (EN = El Niño; LN = La Niña; D = Drought; T = Typical). Source: CMORPH.

The precipitation patterns were determined from the monthly data recorded per grid square in the study area during the study period, between January, 1998, and December, 2016, based on a Principal Components Analysis (PCA). The number of principal components (PCs) was determined by Kaiser's truncation criterion. The significance of the coefficients was evaluated using the KMO and Bartlett's test of sphericity (WILKS, 2006). The significance of the trends in the series of eigenvalues (coefficients of temporal expansion) was determined by the Mann-Kendall test (MANN, 1945; KENDALL, 1975), while the significance of the eigenvectors (coefficients of spatial expansion) was tested using Student's t. The data matrix was organized as in the studies of Amanajás and Braga (2012) and Silva Santos et al. (2016).

\section{RESULTS}

\subsection{MONTHLY VARIATION}

Rainfall peaked between January and June (Figure 4), with mean monthly precipitation ranging from $270 \mathrm{~mm}$ to $600 \mathrm{~mm}$. The lowest monthly rainfall was recorded between July and December, with values ranging from $0 \mathrm{~mm}$ to 120 $\mathrm{mm}$. In sector 1 , the highest monthly rainfall was recorded in March ( $>540$ $\mathrm{mm})$, and the lowest in September $(<60 \mathrm{~mm})$. In sector 2, the highest rainfall ( $>570 \mathrm{~mm}$ ) was also recorded in March, while the lowest ( $<30 \mathrm{~mm}$ ) was recorded in October. Sector 3 presented the greatest extremes, with a peak in March (> $600 \mathrm{~mm}$ ) and a low of $0 \mathrm{~mm}$ in November. Monthly rainfall at the coastline was below $30 \mathrm{~mm}$ between August and November. 

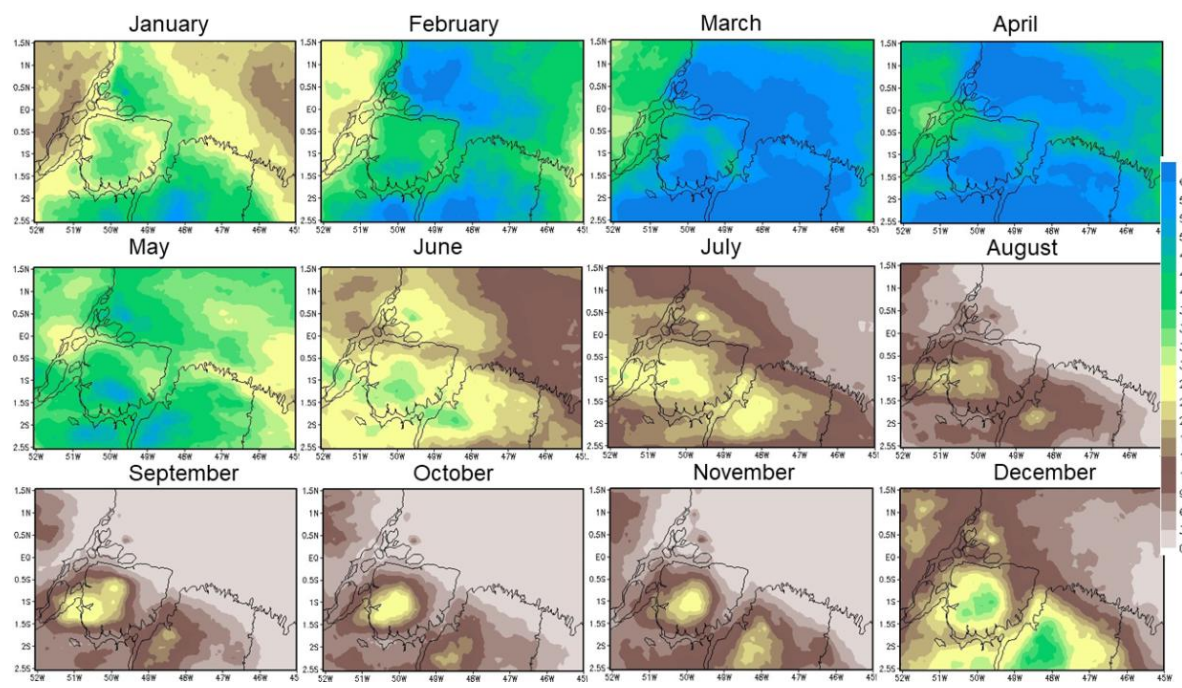

Figure 4 - Mean monthly precipitation $(\mathrm{mm})$ recorded in the study region in the Amazon coastal zone between 1998 and 2016.

\subsection{SEASONAL VARIATION}

In the early rainy season (Figure 5A), precipitation ranged from $240 \mathrm{~mm}$ at the coastline to $500 \mathrm{~mm}$ further inland, with a clear zonal gradient between the lower rainfall in sector 3 and the peaks in sectors 1 and 2. The spatial distribution of the precipitation shifts during the peak rainy season, becoming almost uniform, with total precipitation of between $460 \mathrm{~mm}$ and $600 \mathrm{~mm}$ in all three sectors (Figure 5B). During the rainy-dry transition period, precipitation ranged from $40 \mathrm{~mm}$ in sector 3 to over $120 \mathrm{~mm}$ in sectors 1 and 2 (Figure 5C). At the peak of the dry season, most of the study region received minimal amounts of rain, principally in sector 3. On the mainland, in sectors 1 and 2, precipitation on the coastline varied between $0 \mathrm{~mm}$ and $30 \mathrm{~mm}$ (Figure 5D).
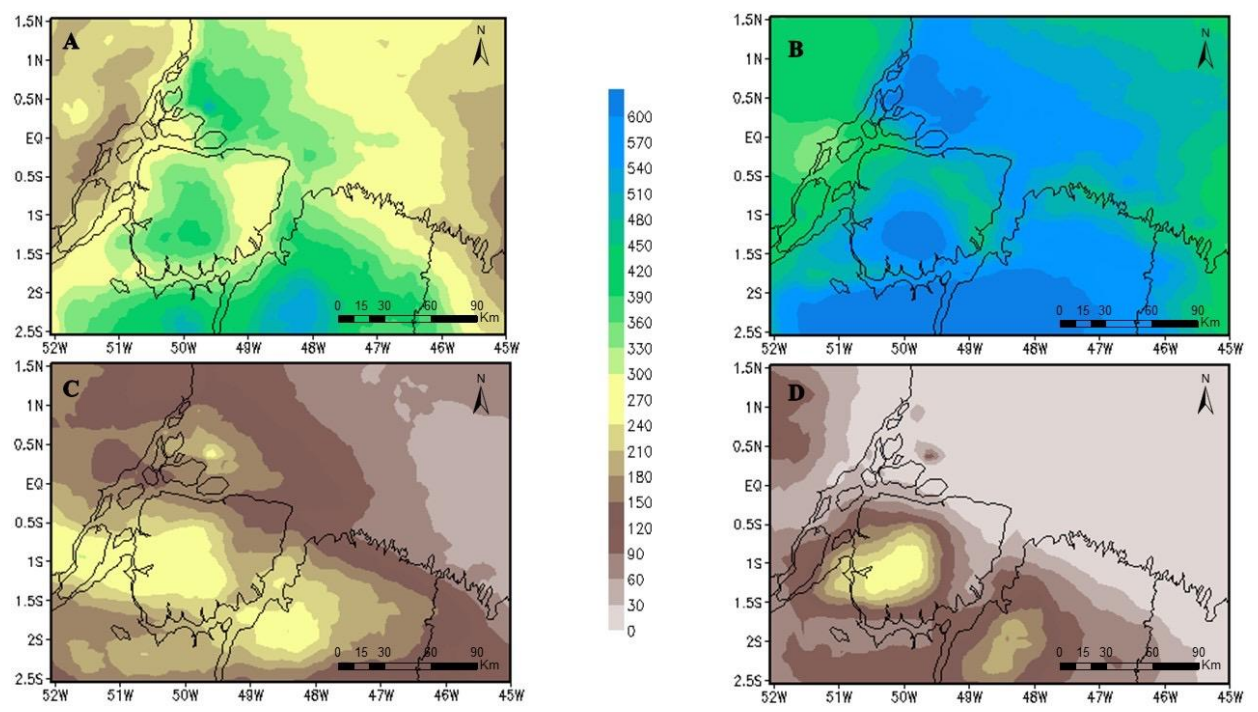

Figure 5 - Mean seasonal precipitation $(\mathrm{mm})$ in the study region in the Amazon coastal zone, recorded between 1998 and 2016: (A) early rainy season; (B) peak rainy season; (C) rainy-dry transition period; and (D) peak dry season. 


\subsection{ANNUAL VARIATION}

During the El Niño years (Figure $6 \mathrm{~A}, \mathrm{~B}$ ), the annual rainfall had a highly heterogeneous distribution within the study region, ranging from highs of more than $2000 \mathrm{~mm}$ in sectors 1 and 2 to lows of less than $1500 \mathrm{~mm}$ in sector 3 . Annual precipitation on the coastline was $1000-1800 \mathrm{~mm}$. Rainfall was more intense over the mainland (sectors 1 and 2) during the 2015 El Niño event, however, reaching $2000 \mathrm{~mm}$ near the coast (Figure 6B). During the La Niña events, rainfall had a more homogeneous distribution in all three sectors, reaching values of over $3000 \mathrm{~mm}$ (Figure 6C,D). While precipitation did not vary noticeably within the study area, relatively low values, of approximately 2300 $\mathrm{mm}$, were recorded during La Niña events in the neighboring Brazilian state of Amapá, located to the northwest of the study area (Figure 6D).

During drought years (Figure $6 \mathrm{E}, \mathrm{F}$ ), rainfall was distributed heterogeneously, with total precipitation of less than $1000 \mathrm{~mm}$ over the ocean (sector 3), but reaching over $2900 \mathrm{~mm}$ on the mainland (sectors 1 and 2), reflecting a north-south gradient. The 2012 drought was more intense on the coastline, where annual precipitation of less than $1000 \mathrm{~mm}$ was recorded (Figure 6F).

In typical years, annual precipitation ranged from $1500 \mathrm{~mm}$ in the western extreme of sector 1 and eastern extreme of sector 2 to $2700 \mathrm{~mm}$, in the center of the study area (Figure 6G,H). In the typical year 2014, annual precipitation was higher along the coastline in comparison with 2002, reaching values of over $2100 \mathrm{~mm}$ (Figure $6 \mathrm{H}$ ).

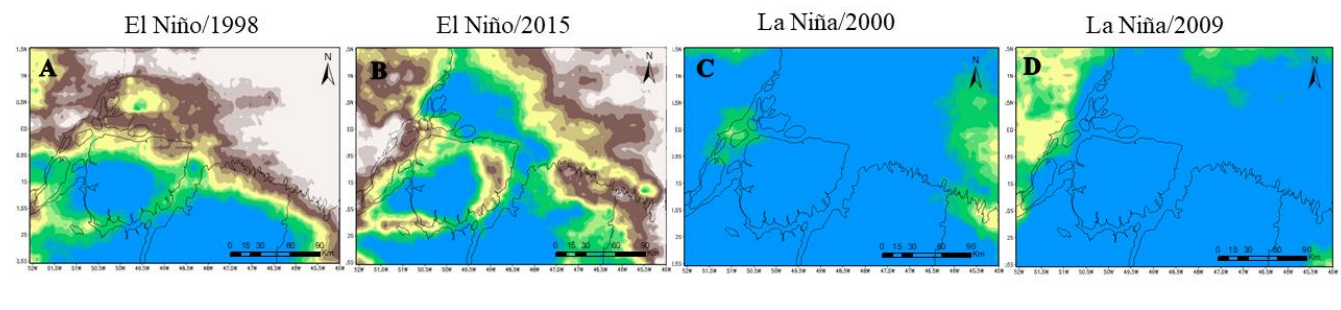

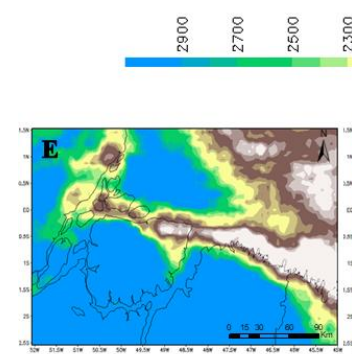

Drought $/ 2005$

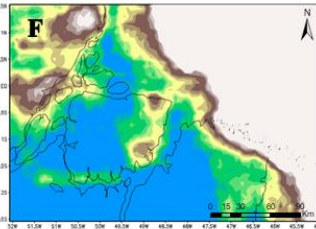

Drought $/ 2012$

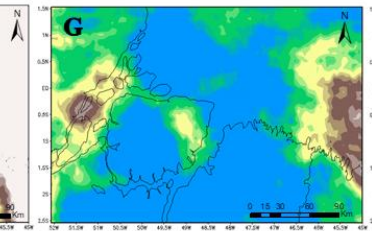

Typical/2002

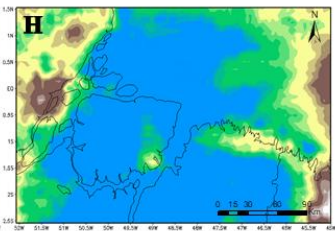

Typical/2014

Figure 6 - Spatiotemporal distribution of the annual precipitation $(\mathrm{mm})$ recorded in the study area in the atypical years of the study period: (A) 1998 (El Niño), (B) 2015 (El Niño), (C) 2000 (La Niña), (D) 2009 (La Niña), (E) 2005 (Drought), (F) 2012 (Drought), and two typical years: (G) 2002 and (H) 2014.

\subsection{PRECIPITATION PATTERNS}

The Principal Components Analysis (PCA) of the spatial and temporal factors derived from the high-resolution $\mathrm{CMORPH}$ estimates of the monthly 
precipitation patterns revealed that the first two principal components (PCs) together explained $88 \%$ of the total variance in the data. The majority of this variance $(83 \%)$ was explained by the first factor, that is, the spatial pattern (Figure 7A), with positive correlations indicating higher precipitation rates, with values of $0.78-0.98$ throughout the study area. The highest coefficients (0.930.93) were concentrated in two major zones or "cells", one of which was located over the ocean (sector 3) off Marajó Island (sector 1), with the second off the northeastern extremity of Pará (northeast of sector 2). The lowest coefficients, ranging from 0.78 to 0.80 were also arranged in two zones or "cells", one to the southwest of Marajó Island (sector 1 ) and the second to the southwest of sector 2.

The spatial pattern of the second component, representing $5 \%$ of the total variance, presented correlations ranging from 0.5 to -0.35 throughout the study area (Figure 7B). This north-south patterns begins with negative values over the ocean (sector 3 ), reflecting lower precipitation rates, with increasingly higher values towards the mainland, and progressively inland (sector 2), with the most intense concentration of precipitation corresponding to a "cell" to the southwest of Marajó Island (sector 1).

The mean temporal variation in the first two principal components, which together account for $88 \%$ of the variance in the data, is shown in Figure 7C and D. Figure 7C represents the first temporal factor, which corresponds to $83 \%$ of the total variance in the data, with positive contributions between January and May, and values exceeding 1.5 in March. Negative values were recorded between June and December, peaking at over -0.9 in October and November. Figure 7D shows the second temporal factor (PC2), which explains $5 \%$ of the total variance in the data, with values of -0.0 to -0.8 between January and March, with values of -0.1 between August and November. Positive values were recorded between April (0.3) and July (0.08), and then in December (0.7), which returned the highest positive values, while the lowest value $(-0.8)$ was recorded in February.

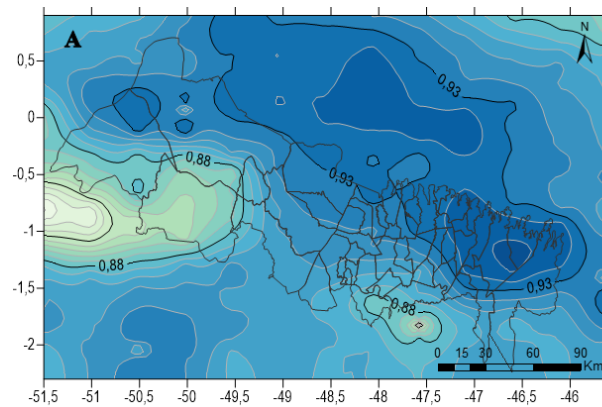

C

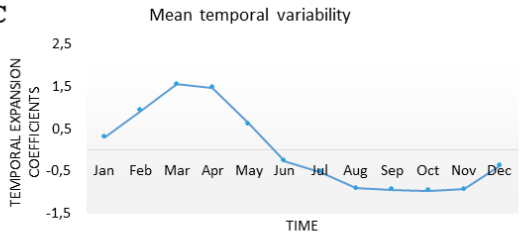

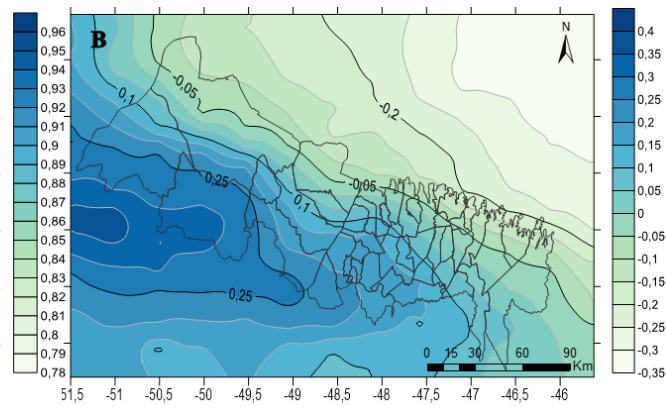

D

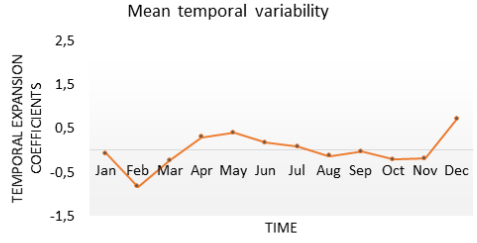

$\rightarrow$ Factor 2

Figure 7 - The spatial pattern of (A) PC1 (83\% of the variance), (B) PC2 (5\% of the variance), and the mean temporal variability of $(C)$ the first principal component and (D) the second principal component. 
To ratify these findings, the greatest positive and negative coefficients were verified to confirm the accuracy of the PCA and the diagnostic potential of the CMORPH technique. The spatial heterogeneity of the positive pattern (Figure $8 \mathrm{~A}$ ) reveals the concentration of monthly precipitation in the $700-800 \mathrm{~mm}$ range in two distinct areas - one over the ocean (sector 3) and the other over the mainland (sector 1 and 2) - which is consistent with the principal pattern, that is, the existence of two "cells" of high precipitation levels. The negative plot (Figure 8B) presents variation in the precipitation, with monthly values of less than $20 \mathrm{~mm}$ along the whole length of the coastal sector, with the exception of an area to the south of Marajó Island (sector 1), which has a value of $140 \mathrm{~mm}$.

The temporal variation in the first principal component (Figure $8 \mathrm{C}$ ) indicates that April, 2010, was the month with the highest positive coefficient (2.24), while November, 2008, had the lowest negative coefficient $(-1.16)$. The positive coefficients indicate a higher concentration of rainfall, whereas negative values indicate a reduction in the precipitation, with an inversion of the predominant pattern, i.e., locations that had higher rainfall were less rainy.
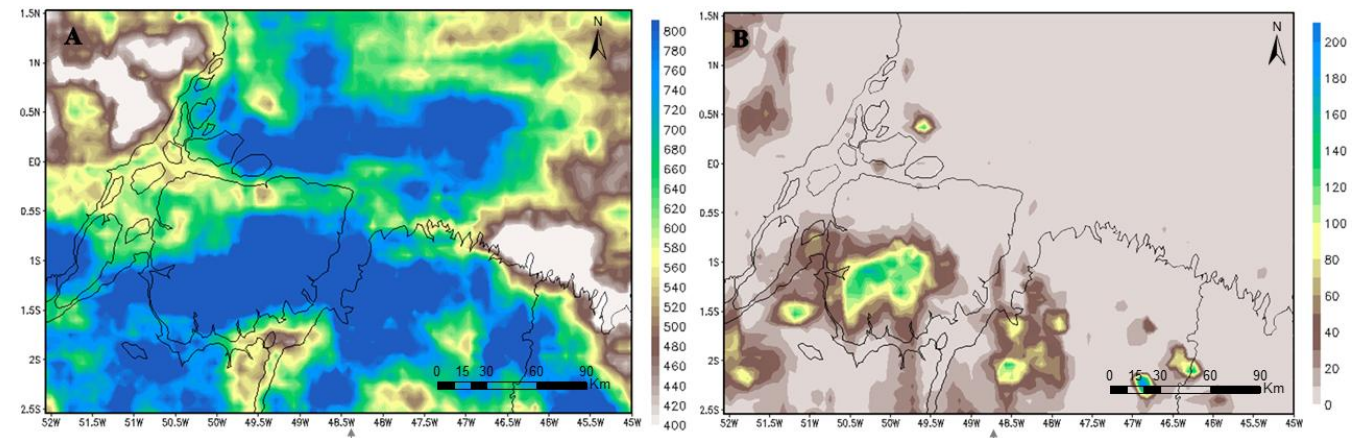

C Temporal variability of factor 1

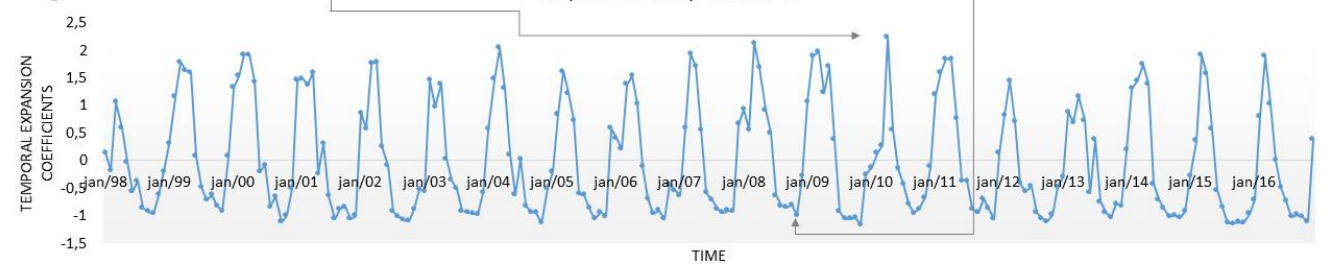

Figure 8 - Principal Component 1: (A) Distribution of the monthly precipitation that correlated most with the pattern confirmed by the CMORPH analysis - April, 2010; (B) Distribution of the monthly precipitation that correlated least with the pattern confirmed by the CMORPH analysis - November, 2008; (C) temporal variation in the first principal component.

In the analysis of the second principal component, a concentration of precipitation (monthly rainfall of $400-760 \mathrm{~mm}$ ) can be seen over the mainland, i.e., sectors 1 and 2 (Figure 9A), together with an absence of precipitation over the ocean (sector 3 ). Figure $9 \mathrm{~B}$ shows the variation in the precipitation, with peaks of up to $800 \mathrm{~mm}$ over the ocean (sector 3), and lows of $400 \mathrm{~mm}$ over the mainland (sectors 1 and 2). The analysis of the temporal contribution of the second principal component (Figure 9C) shows that December, 2005, had the highest positive coefficient (3.5), while February, 2003, had the lowest negative coefficient (-3.3). Once again, the positive coefficients indicate a higher concentration of rainfall, whereas negative values reflect a reduction in the precipitation, and an inversion of the predominant pattern (locations that had higher rainfall were less rainy). 

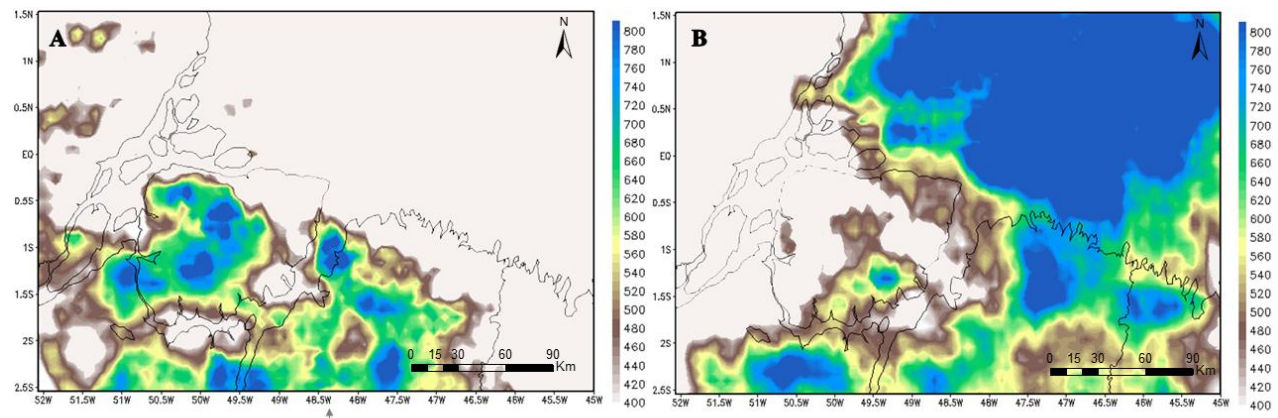

C

Temporal variability of factor 2

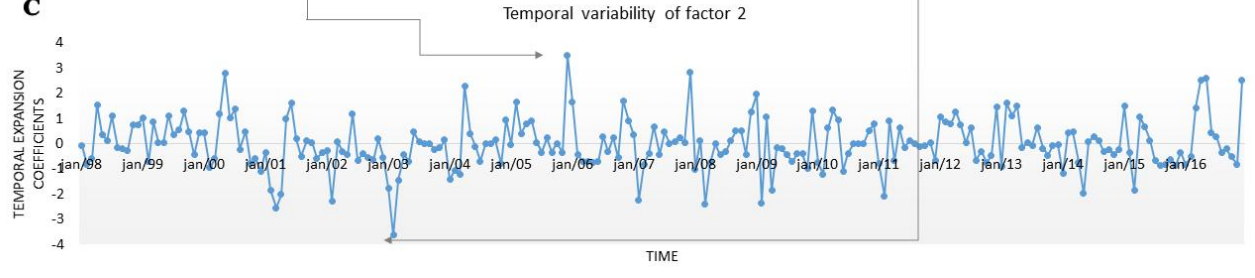

Figure 9 - Principal Component 2: (A) Distribution of the monthly precipitation that correlated most with the pattern confirmed by the CMORPH analysis - December, 2005; (B) Distribution of the monthly precipitation that correlated least with the pattern confirmed by the CMORPH analysis - February, 2003; (C) temporal variation in the second principal component.

\section{DISCUSSION}

In the study region, on the Amazon coast, monthly rainfall during the first half of the year was typically between $100 \mathrm{~mm}$ and $600 \mathrm{~mm}$, whereas in the second half of the year, precipitation rates were much lower, between $0 \mathrm{~mm}$ and $200 \mathrm{~mm}$, which is consistent with the typical rainy-dry season cycle of the study region (FISCH et al., 1998; MOLION, 2000; MORAES et al., 2005). The more refined approach of the CMORPH technique nevertheless provides more detailed insights into the temporal distribution of the rainfall in the areas that would otherwise depend on the relatively crude interpolation of the data obtained from terrestrial meteorological stations. For example, in the southeastern corner of sector 2 , which coincides with the metropolitan region of the Pará state capital, Belém, the rains begin to intensify in December, whereas in the northern portion of this sector, the rains only begin to peak in January.

The Intertropical Convergence Zone (ITCZ) is the system that most contributes to the precipitation patterns during the rainy season, that is, the first half of the year (MOLION, 1987), although the High Level Cyclonic Vortices (HLCVs) also play a role at the regional level (REIBOTA et al., 2010). By contrast, the precipitation recorded during the transition period and the peak dry season are formed by mesoscale and local systems, such as Lines of Instability (COHEN et al. 1995). The precipitation in the study region is the result of the interaction of different atmospheric mechanisms associated with the ocean, that is, the North Atlantic Oscillation (NAO), Pacific Decadal Oscillation (PDO), and El Niño Southern Oscillation, ENSO (HURRELL et al. 2008), together with other meteorological systems that function at distinct times and scales, resulting in an intense mixture of effects that determines the enormous spatial and temporal variability found in the region's rainfall patterns (MARENGO et al. 2001; NOBRE et al. 2009). 
The difference between the peak precipitation level recorded in the months of the first half of the year $(600 \mathrm{~mm})$ and the absolute minimum ( 0 $\mathrm{mm}$ ) recorded in the second half is the result of the absence of major precipitant systems during the latter period, which makes the atmosphere clearer (SILVA SANTOS et al., 2016). Amanájas and Braga (2012) found that, while the rainy season is well-defined, there is considerable variation between the minimum and maximum precipitation rates recorded along the coastal region, leading to the establishment of homogeneous zones in distinct areas and periods. In coastal regions, the homogenization of the precipitation in distinct zones demands investigation, given the differential spatialization of the rainfall within a relatively homogeneous environment, i.e., the littoral. In this context, the results of the present study both corroborate and refine the findings of Amanajas and Braga (2012), which elucidate seasonal rainfall patterns, and provide important insights for the development of public policies for environmental management, that should mediate the vulnerability of local municipalities based on the quantification of climatic patterns.

The monthly, seasonal, and annual data produced by the CMORPH approach indicated a surplus of rainfall during the first half of the year (JanuaryJune), with monthly precipitation of 360-600 mm. However, a number of studies, such as those of Behrangi et al. (2011) and Sodré et al. (2013), have shown that the CMORPH data tend to overestimate the amount of rainfall during the rainy season, during the first half of the year, when the incidence of sunlight in the Amazon region is at its peak (austral summer). In the United States, Tian et al. (2007) used the CMORPH technique to analyze daily climate data and found that this approach tended to overestimate precipitation significantly during warmer periods. The performance of the CMORPH technique may thus depend on the time of year, with precipitation being overestimated significantly during warmer periods (December-May) while underestimating this parameter slightly during cooler periods (June-November), as confirmed by Zeweldi and Gebremichael (2009). In comparison with the other remote-sensing procedures used to estimate precipitation, however, the CMORPH technique results in a greater underestimation at almost all time scales, given that it is not calibrated using ground-based data (ABERA et al., 2016; RINGARD et al., 2015; LO CONTI et al., 2014).

During El Niño years, rainfall is distributed heterogeneously in the eastern Amazon region, with a marked reduction in precipitation in comparison with typical years, and in particular, La Niña events (MARENGO et al., 2011b). Grimm and Tedeschi (2011) and Sun et al. (2015) identified differentiated temporal patterns in the occurrence of El Niño and La Niña events in coastal regions. On the coast of China, Chen et al. (2018) found that higher rates of erosion were associated with El Niño events. The annual CMORPH data presented here indicate that precipitation is overestimated in El Niño or drought years (e.g., 1998, 2005, 2012, 2013, and 2015), with the opposite trend occurring in typical and La Niña years (e.g., 2000, 2009, and 2011). The extreme climatic conditions provoked by ENSO events also affect the hydrodynamic and hydrological systems of coastal and estuarine areas (PEREIRA et al., 2013; MORTLOCK, GOODWIN, 2016; PEREIRA et al., 2017).

The positive peaks in the rainfall patterns recorded in the present study between January and May (Figure $8 \mathrm{~A}, \mathrm{C}$ ) are related clearly to the presence of the Intertropical Convergence Zone, or ITCZ (SILVA SANTOS et al., 2016; 
SANTOS et al., 2017). The ITCZ is a large-scale tropical system that is the primary determinant of the rains in the Amazon region, principally during the first half of the year (MOLION, 1993). In normal years, the ITCZ migrates to a more southerly position in the southern hemisphere, especially in March and April, when the highest positive values were recorded (Figure 8C). Uvo (1989) found that the duration of the presence of the ITCZ at its southern extreme (i.e., whether it remains in position for a shorter or longer period) is the principal factor determining the quality of the rainy season in the Amazon region.

In the second pattern, the highest positive values are recorded between April and July, when the high precipitation rate may be related to the higher frequency of the lines of instability that arise in the Amazon region between April and June (see Alcântara et al., 2011). These lines are a mesoscale precipitant system that may both provoke and disperse rainfall in the region, and account for $45 \%$ of the precipitation in eastern Pará (COHEN et al., 1989). The north-south precipitation dipole (Figure 8B) may be linked to the occurrence of lines of instability of types 1 and 2 over the mainland at a distance of more than $170 \mathrm{~km}$ from the coast of Pará, induced by the systems of sea breezes and local winds (MOLION, 1987; COHEN et al., 1995; MATOS et al., 2016).

Satellite-based applications, such as the CMORPH system, perform best in areas of low to medium altitudes (ZAMBRANO-BIGIARINI et al., 2017), and are thus appropriate for the low-lying Amazon coast (SOUZA FILHO et al., 2005). Tian and Peters-Lidard (2010) also found that remote sensing data, including those generated by the CMORPH technique, are more reliable in areas subject to strong convective precipitation over flat surfaces, such as the tropical ocean and much of South America. From this perspective, the Amazon region provides an optimal scenario for the application of this type of analytical approach, given that it is mostly low-lying and flat, and that its climate is characterized by intense convective activity (ADAMS et al., 2009). This further reinforces the importance of the present study, which was based on the spatialization of the high-resolution precipitation data obtained from the CMORPH approach for the Amazon coastal zone, and has enormous potential for deployment in other coastal regions that have similar topographic characteristics.

\section{FINAL CONSIDERATIONS}

Fine-scale, satellite-based estimates of precipitation rates, such as those derived from the CMORPH technique, provide important insights for the development of more systematic meteorological and hydrological research, in particular in areas with scant terrestrial data. In the present study, we evaluated for the first time the spatial and temporal variability of the highresolution CMORPH product of the coastal zone of the Brazilian Amazon region, for the period between 1998 and 2016. The region has high rainfall rates, but a relatively small network of meteorological stations. The most important conclusions are presented below.

The analysis of the monthly variation in the data was satisfactory and accurate, and was consistent with the known precipitation pattern in the Amazon region, which is divided into a rainy season in the first half of the year 
(January-June) and a dry (or less rainy) season in the second half (JulyDecember). On the coast, the peak rainfall is recorded up to May. The rainy season - both the early and peak months - presented the highest precipitation rates, with the lowest rates being recorded in the dry season, including both the rainy-dry transition period and the peak dry season months. In addition, precipitation on the coastline during the rainiest months (March-May) was lower than that recorded over the ocean and further inland. The analysis of annual patterns also revealed that years with extreme climatic events (i.e., ENSO) presented characteristics shifts in the intensity and distribution of precipitation over the mainland, either increasing or decreasing, depending on the exact phenomenon (El Niño or La Niña).

The principal seasonal precipitation pattern observed in the region, that is, a peak in rainfall in March and a low in October and November, was influenced primarily by large scale precipitant systems. The spatial distribution of precipitation patterns nevertheless reflects a mesoscale dynamic, with highs over the ocean and the mainland, but relatively little variation along the coastline, an area of confluence. A secondary pattern is the contribution of meso- and local scale systems, together with land use and cover, which modulate their influence and relationships. In general, local precipitation patterns are influenced by a combination of precipitant systems that together determine local rainfall rates. Shifts in land use and cover also have an influence, primarily at a local scale, as verified by the high-resolution CMORPH data.

It is nevertheless important to assess with caution the performance of the CMORPH data for the study region, given the evidence that this technique may be limited to certain specific types of precipitation event, as well as having important biases and the possibility of the false detection of precipitation. Even so, the present study supports the application of remote sensing data at a refined scale for the coastal zone of the Amazon and other areas that have a limited network of meteorological stations and scant or incomplete precipitation data. In this scenario, the CMORPH technique provides an efficient and accurate representation of local precipitation patterns, providing more systematic input for the development of more reliable hydrological and climatic models, based on an empirical spatiotemporal database, rather than the interpolation of data from widely-dispersed points. Data of this quality are fundamentally important for reliable planning and the adequate development of public policies for the effective management of the problems arising from extreme climatic conditions and the socio-environmental vulnerability of local populations.

\section{REFERENCES}

ABERA, W.; BROCCA, L.; RIGON, R. Comparative evaluation of different satellite rainfall estimation products and bias correction in the Upper Blue Nile (UBN) basin. Atmospheric research, v. 178, p. 471-483, 2016.

ADAMS, D. K; SOUZA, E. P .; COSTA, A. A. Wet convection in the Amazon: implications for numerical modeling. Brazilian Journal of Meteorology, v. 24, n. 2, p. 168-178, 2009.

ALCÂNTARA, C.R .; SILVA DIAS M. A. F .; SOUZA, E. P .; COHEN, J. C. P. Verification of the role of low level jets in Amazon squall lines. Atmospheric Research. v.100, p. 36-44, 2011. 
ANdRAde, M. P., MAgAlhães, A., PeReirA, L. C., FloreS-MONTES, M. J., PARDAL, E. C., ANDRADE, T. P., COSTA, R. M. Effects of a La Niña event on hydrological patterns and copepod community structure in a shallow tropical estuary (Taperaçu, Northern Brazil). Journal of Marine Systems, v. 164, p.128-143, 2016.

AMANAJÁS, J.C ; BRAGA, C. C. Pluviometric Space-Temporal Patterns in the Eastern Amazon using Multivariate Analysis. Brazilian Journal of Meteorology, v. 27, n. 4, p. 423434, 2012.

BECKER, B. K. Review of the occupation policies of the Amazon: is it possible to identify models for designing scenarios ?. Strategic partnerships, v.6, n.12, p. 135-159, 2010.

BEHRANGI, A., KHAKBAZ, B., JAW, T. C., AGHAKOUCHAK, A., HSU, K., SOROOSHIAN, S. Hydrologic evaluation of satellite precipitation products over a mid-size basin. Journal of Hydrology, v. 397, n.3-4, p. 225-237, 2011.

BRAZIL. Brazilian Institute of Geography and Statistics (IBGE). Demographic census. Brasília, 2010. Available at: <http://www.cidades.ibge.gov.br//>. Accessed on: March 20. 2018

BRAZIL. National Institute of Meteorology (INMET). Weather station. Brasília, 2010. Available at: <http: //www.inmet.gov.br/portal//>. Accessed on: June 18. 2018.

CHEN, S.; ZHA, X. Effects of the ENSO on rainfall erosivity in the Fujian Province of southeast China. Science of The Total Environment, v. 621, p. 1378-1388, 2018.

COHEN, J. C. P .; Silva Dias, M.A. F .; Nobre, C. A. Climatological aspects of the instability lines of the Amazon. Climanalysis. v. 4, 34-39, 1989.

COHEN, J.C. SILVA DIAS, M. A F .; NOBRE C.A. Environmetal conditions associated with Amazonian squid lines: a case study. Monthy Weather Review, Boston, v. 123, n. 11, p. 3163-3174, 1995.

COHEN, J. C. P .; FITZJARRALD, D.R .; OLIVEIRA, F.A. F .; SARAIVA, I .; BARBOSA, I. R. S .; GANDU, A. W. Radar -observed spatial and temporal rainfall variability near the Tapajos-Amazon confluence. Brazilian Journal of Meteorology. v, 29, p. 23-30, 2014.

CRACKNELL, A. P. Remote sensing techniques in estuaries and coastal zones an update. International Journal of Remote Sensing, v. 20, n. 3, p. 485-496, 1999.

FISCH, G.; MARENGO, J. M .; NOBRE, C. A. A general review on the Amazonian climate. Acta amazônica, v. 28, n. 2, p. 101-126, 1998.

FITZJARRALD, D. R.; SAKA, I. R. K.; MORAES, O. L. L.; DE OLIVEIRA, R. C.; ACEVEDO, O. C.; MATTHEW, J. et al. Spatial and temporal rainfall variability near the AmazonTapajós confluence. Journal of Geophysical Research: Biogeosciences, v.113, n.1, p.1-17. 2008.

GEYER, W. R., BEARDSLEY, R.C., LENTZ, S.J., CANDELA, J., LIMEBURNER, R., JOHNS, W.E., CASTRO, B.M., SOARES, I.D., Physical oceanography of the Amazon Shelf. Cont. Shelf Res. v. 16, p. 575-616, 1996.

GRIMM, A. M; TEDESCHI, R. G. Episódios EL NIÑO e LA NIÑA e a freqüência de eventos extremos de precipitação no Brasil: análise no litoral da região sul. In: XV Congresso Brasileiro de Meteorologia, Florianópolis, SC. 2006.

GRIMM, A.M. Interannual climate variability in South America: impacts on seasonal precipitation, extreme events, and possible effects of climate change. Stoch Environ Res Risk Assess. v. 25, p. 537-554, 2011.

HAILE, A. T .; YAN, F., HABIB, E. Accuracy of the CMORPH satellite-rainfall product over Lake Tana Basin in Eastern Africa. Atmospheric Research, v. 163, p. 177-187, 2015. 
HURRELL, J.W., KUSHNIR, Y., OTTERSEN, G. VISBECK, M. The North Atlantic Oscillation: climatic significance and environmental impact. Washington, DC: American Geophysical Union. (Geophysical Monograph Series), 2003.

IBGE. Instituto Brasileiro de Geografia e Estatística (IBGE). Censo demográfico. Brasília, 2010. Disponível em: <http://www.cidades.ibge.gov.br//>. Acesso em: 20 março. 2018.

JOYCE, R. J.; J.E. JANOWIAK; P. A.; ARKIN; P. X. CMORPH: A method that produces global precipitation estimates from passive microwave and infrared data at high spatial and temporal resolution. Journal of Hydrometeorology, v, 5, p.487-503, 2004.

KENDALL, M. G. Rank correlation measures. London: Charles Griffin, 1975. 220p.

KJERFVE, B., LACERDA, L.D. Mangroves of Brazil. In: Lacerda, L.D. (Ed.), Conservation and Sustainable Utilization of Mangrove Forests in Latin America and Africa Regions. v. 2, p. 245-272, 1993.

KOUSKY, Vernon E. Diurnal rainfall variation in northeast Brazil. Monthly Weather Review, v. 108, n. 4, p. 488-498, 1980.

LO CONTI, F., HSU, K. L., NOTO, L. V., SOROOSHIAN, S. Evaluation and comparison of satellite precipitation estimates with reference to a local area in the Mediterranean Sea. Atmospheric Research, v. 138, p. 189-204, 2014.

MALTHUS, TIM J., AND PETER J. MUMBY. Remote sensing of the coastal zone: an overview and priorities for future research, International Journal of Remote Sensing, v.42, n.13 p. 2805-2815, 2003.

MANN, H. B. Econometrica. The Econometric Society, v. 13, n. 3, p. 245-259, 1945.

MARENGO, J.A .; LIEBMANN, B .; KOUSKY, V. E .; FILIZOLA, N. P .; WAINER, L. C. Onset and End of the Rainy Season in the Brazilian Amazon Basin. Journal of Climate. v. 14, n. 5, p. 833-852, 2001.

MARENGO, J.A., TOMASELLA, J., ALVES, L.M., SOARES, W.R., RODRIGUEZ, D.A. The drought of 2010 in the context of historical droughts in the Amazon region. Geophysical Research Letters, v. 38, p. L12703, 2011b

MATOS, A. P.; COHEN, J. C. P. Breeze circulation and the precipitation band on the east bank of the Marajó bay. Science and nature. v. 38, p. 21-27, 2016.

MOLION, L.C.B., Dynamic climatology of the Amazon region: precipitation mechanisms. Brazilian Journal of Meteorology, v. 2, p. 107-117, 1987.

MOLION, L. C. B. Amazon rainfall and its variability. In: Hydrology and water management in the humid tropics. BONELL, M .; HUFSCHMIDT, M. M .; GLADWELL, J. S. (eds.). International Hydrology Series, Cambrigde University Press, Cambrigde, UK. 1993.

MOLION, L. C. B.; BERNARDO, S. O. Dinâmica das chuvas no Nordeste Brasileiro. In: Congresso Brasileiro de Meteorologia, Anais. (CD-ROM). Rio de Janeiro. 2000.

MORTLOCK, T.R., GOODWIN, I. D. Impacts of enhanced central Pacific ENSO on wave climate and headland-bay beach morphology. Continental Shelf Research, v. 120, p. 1425, 2016.

MORAES, B. C., DA COSTA, J. M. N., DA COSTA, A. C. L., COSTA, M. H. Spatial and temporal variation of precipitation in the state of Pará Acta Amazônica, v. 35, p. 207217, 2005.

NOAA, National Oceanic and Atmospheric Administration. Southern Oscillation Index. disponível em: https://www.ncdc.noaa.gov/teleconnections/enso/indicators/soi/. Acessado em 29/02/2017. 
NOBRE, C.A .; OBREGON, G.O .; MARENGO, J.A .; FU, R .; POVEDA, G. Characteristics of Amazonian Climate: Main Reatures. In: GASH, J.; KELLER, M .; BUSTAMANTE, M. and SILVA DIAS, P. Amazonia and Global Change, p. 149-162, 2009.

PEREIRA, L.C.C., MENDES, C.M., MONTEIRO, M.C., ASP, N.E., Morphological and sedimentological changes in a macrotidal sand beach in the Amazon Littoral (Vila dos Pescadores, Pará, Brazil). Journal of Coastal Research, p.113-117. 2009.

PEREIRA, L. C. C., DE OLIVEIRA, S. M. O., DA COSTA, R. M., DA COSTA, K. G., \& VILACONCEJO, A. What happens on an equatorial beach on the Amazon coast when La Niña occurs during the rainy season?. Estuarine, Coastal and Shelf Science, v. 135, p. 116127, 2013.

PEREIRA, L. C. C., VILA-CONCEJO, A., DA COSTA, R. M., \& SHORT, A. D. Managing physical and anthropogenic hazards on macrotidal Amazon beaches. Ocean \& coastal management, v. 96, p. 149-162, 2014.

PEREIRA, L.C C., DA COSTA, Á. K. R., DA COSTA, R. M., MAGALHÃES, A., DE JESUS FLORES-MONTES, M., JIMÉNEZ, J.A. Influence of a Drought Event on Hydrological Characteristics of a Small Estuary on the Amazon Mangrove Coast. Estuaries and Coasts, p. 1-14, 2017.

REBOITA, M. S., GAN, M. A., ROCHA, R. P. D., AMBRIZZI, T. Regimes de precipitação na América do Sul: uma revisão bibliográfica. Revista Brasileira de Meteorologia, v.25, n. 2, p.185-204, 2010.

RINGARD, J .; BECKER, M .; SEYLER, F., LINGUET, L. Temporal and spatial assessment of four satellite rainfall estimates over French Guiana and North Brazil. Remote Sensing, v. 7, n.12, p. 16441-16459, 2015.

RODRIGUEZ, J.J; WINDEVOXHEL, N. J. Análisis regional de la situación de la zona marina costera centroamericana. Banco Inter-Americano de Desenvolvimiento BID. Washington. D.C. No ENV - 121. 1998.

ROGELIS, M. C.; WERNER, M. G. F. Spatial interpolation for real-time rainfall field estimation in areas with complex topography. Journal of Hydrometeorology, v. 14, n. 1 , p. 85-104, 2013.

ROPELEWSKI, C. F .; HALPERT, M. S. Global and regional scale precipitation patterns associated with EI Nino / Southern Oscillation. Monthly Weather Review, v. 115, n. 2, p. 1606-1626, 1987.

SANTOS, M. R., VITORINO, M. I., DA SILVA PIMENTEL, M. DE OLIVEIRA SOUTO, J. I. Analysis of the spatial-temporal distribution of rainfall in the metropolitan mesoregion of Belém-Pará: contributions of the remote sensing technique. Paths of Geography, v. 18, $\mathrm{n}$. 62, p. 49-58, 2017.

SILVA SANTOS, M. R., VITORINO, M. I., BRAGA, C. C., OLIVEIRA SOUTO, J. I., MOURA, M. N., JUNIOR, P. P. F. Monthly precipitation patterns in the metropolitan Belém mesoregion: use of CMORPH and main components. Revista Brasileira de Geografia Física, v. 9, n. 7, p. 2301-2311. 2016.

SCHERER, M.; SANCHES, M.; NEGREIROS, D. H. "Management of coastal zones and public policies in Brazil: a diagnosis" Barragán Muñoz, J.M. (coord.). Integrated Coastal Management and Public Policy in Ibero-America: A diagnosis. Need for Change. Red IBERMAR (CYTED), Cádiz, p. 292-384, 2010.

SODRÉ, G.R.C.; RODRIGUES, L. L. M.; Comparison Between Estimation of Precipitation Observed by the CMORPH Technique and INMET Meteorological Stations in Different Regions of Brazil. Brazilian Journal of Physical Geography, v. 6, n. 2, p. 301-307, 2013.

SOUZA FILHO, P. W. M .; SALES, M. E. C .; PROST, M. T. R. C .; COSTA, F. R .; SOUZA, L.F. M. O. Amazon Coastal Zone: the regional scenario and $S \& T$ indicators. In: SOUZA 
FILHO, P. W. M; CUNHA, E.R. S. P .; SALES, M. E. C .; SOUZA L. F. M. O .; COSTA, F. R. (eds.). Bibliography of the Amazon Coastal Zone: Brazil. Belém: MPEG; UFPA; PETROBRÁS, p. 9-20, 2005

SUN, X., RENARD, B., THYER, M., WESTRA, S., LANG, M. 2015. A global analysis of the asymmetric effect of ENSO on extreme precipitation. Journal of Hydrology, 530, 51-65.

TIAN, Y., C. D. PETERS-LIDARD, B. J. CHAUDHURY, AND M. GARCIA, Multitemporal analysis of TRMM-based satellite precipitation products for land data assimilation applications. Journal of Hydrometeorology, v. 8, n.6, p.1165-1183, 2007.

TIAN, Y.; PETERS-LIDARD, C. D. A global map of uncertainties in satellite-based precipitation measurements. Geophysical Research Letters, v. 37, n. 24, 2010.

TOMLINSON, C. J., CHAPMAN, L., THORNES, J. E., BAKER, C. Remote sensing land surface temperature for meteorology and climatology: A review. Meteorological Applications, v.18, n.3, p. 296-306, 2011

TRALLI, D. M., BLOM, R. G., ZLOTNICKI, V., DONNELLAN, A., EVANS, D. L.. Satellite remote sensing of earthquake, volcano, flood, landslide and coastal inundation hazards. Journal of Photogrammetry and Remote Sensing, v. 59, n.4, p.185-198, 2005

UVO, C. R. B. The Intertropical Convergence Zone (ITCZ) and its relation with the precipitation of the Northern Region of the Northeast of Brazil. INPE, 1989.

VERWORN, A.; HABERLANDT, U. Spatial interpolation of hourly rainfall-effect of additional information, variogram inference and storm properties. Hydrology and Earth System Sciences, v. 15, n. 2, p. 569-584, 2011.

WILKS, D. S. Statistical Methods in the Atmospheric Sciences. 2. ed. London, Academic Press, 2006. 649p.

WOLDEMESKEL, F. M., SIVAKUMAR, B., SHARMA, A. Merging gauge and satellite rainfall with specification of associated uncertainty across Australia. Journal of Hydrology, v. 499, p. 167-176. 2013.

ZAMBRANO-BIGIARINI, M., NAUDITT, A., BIRKEL, C., VERBIST, K., RIBBE, L. Temporal and spatial evaluation of satellite-based rainfall estimates across the complex topographical and climatic gradients of Chile. Hydrology and Earth System Sciences, v.21, n.2, 1295-1320, 2017.

ZEWELDI, D. A., GEBREMICHAEL, M. Evaluation of CMORPH precipitation products at fine space-time scales. Journal of Hydrometeorology, v. 10, n.1, p. 300-307, 2009. 